\title{
Carbon and nutrient stocks of tea plantations differing in age, genotype and plant population density
}

\author{
D. M. Kamau • J. H. J. Spiertz • O. Oenema
}

Received: 2 October 2007 / Accepted: 18 February 2008/Published online: 18 April 2008

(C) The Author(s) 2008

\begin{abstract}
Tea (Camellia sinensis L.) is a perennial evergreen shrub managed intensively for continuous growth of young shoots. Most tea plantations were established at the expense of native forest. Change in carbon (C) and nutrient (nitrogen, phosphorus, potassium (NPK)) accumulation in forests over time has been intensively studied, but how C and NPK stocks in tea plantations are associated with age, genotype and plant density have not been reported yet in literature. To get a better insight in the effects of age and the associated change in genotype (clone or seedling) and density on C and NPK stocks data were collected in a chronosequence of tea plantations by destructive sampling of whole tea bushes. Four plantations differing in age (76-, 43-, 29- and 14-year
\end{abstract}

Responsible Editor: Len Wade.

D. M. Kamau

Tea Research Foundation of Kenya,

P.O. Box 820-20200, Kericho, Kenya

D. M. Kamau • J. H. J. Spiertz $(\bowtie)$

Crop and Weed Ecology Group, Plant Sciences,

Wageningen University,

P.O. Box 430, 6700 AK Wageningen, The Netherlands

e-mail: huub.spiertz@wur.nl

O. Oenema

Soil Quality Group, Environmental Sciences,

Wageningen University/Alterra,

P.O. Box 47, 6700 AA Wageningen, The Netherlands old) and genotype-density combinations were selected. The 76- and 43-year old plantations were composed of seedlings planted at a relative low density: a spacing of $1.52 \times 0.91 \mathrm{~m}$ and $1.22 \times$ $1.22 \mathrm{~m}$, respectively, whereas in the 29- and 14-year old plantations an improved clonal cultivar was grown at higher plant densities: a spacing of $1.22 \times$ $0.61 \mathrm{~m}$ and $1.22 \times 0.76 \mathrm{~m}$, respectively. Total dry matter weights $(\mathrm{DM})$ of tea bushes increased with age from 9.0 to $11.5 \mathrm{~kg}$ in clonal bushes and from 13.5 and $19.9 \mathrm{~kg}$ in seedling bushes for the 14- and 29-year, and the 43- and 76-year old plantations, respectively. Most DM was stored in the woody tissue of the tea bush frame. Total C-stocks expressed per unit area (ha) amounted to 44 and 72, and 43 and $69 \mathrm{t} \mathrm{C} \mathrm{ha}^{-1}$ for clonal and seedling bushes, respectively. Total $\mathrm{N}$ stocks ranged from 732 to 995 and from 734 to $1,200 \mathrm{~kg} \mathrm{ha}^{-1}$, P stocks from 78 to 120 and from 67 to $92 \mathrm{~kg} \mathrm{ha}^{-1}$, and $\mathrm{K}$ stocks from 775 to 901 and from 646 to $1,120 \mathrm{~kg} \mathrm{ha}^{-1}$ for clonal and seedling bushes, respectively. It is concluded that older stands of seedling and clonal tea plantations result in higher $\mathrm{C}$ and NPK stocks. Higher stocks may be functional in maintaining yield stability under adverse weather conditions. Plantations with higher nutrient stocks are less responsive to nutrient supply and therefore will require lower fertilizer applications.

Keywords Biomass · Nitrogen · Phosphorus · Potassium $\cdot$ Clonal $\cdot$ Seedling 


\section{Introduction}

Tea (Camellia sinensis L.) is a perennial evergreen shrub managed intensively by periodically lopping to form a table facilitating plucking, either by hand or machine. Tea plantations in Kenya occupy a large acreage of agricultural land measuring over 136,700 ha in 2004. The plantations are mainly located in high-potential areas categorised as Lower Highland Zone-LH1, and Upper Middle ZoneUM1 (Jaetzold and Schmidt 1982; Sombroek et al. 1980). These zones have fragile soils and comprise of the $10 \%$ of total area under indigenous forest (Oglethorpe and Oliech 1992) representing a large fraction of the forest area in Kenya (Anonymous 2004). The forest area continues to decrease as a result of the expansion in land used for agriculture, overgrazing, commercial timber harvesting, overexploitation for fuel wood and fencing poles, and general industrial and settlement development. An example is the Kakamega Forest in western Kenya where $50 \%$ (14,000 ha) of the indigenous forest cover was cleared in a time-span of 30 years (Wass 1995). On a global scale, an estimated 13 million ha of forests in the tropics are lost each year (FAO 1999). Although tea plantations accumulate less biomass than tropical forests and mature plantation trees, these perennial agroecosystems imply a sustained carbon (C) sequestration in fragile areas.

Pastures store most of their carbon and nitrogen belowground as soil organic matter. In contrast, forests often store large amounts of organic matter aboveground in woody plant tissue and fibrous litter (Sharrow and Ismail 2004). Reported data on carbon and nutrients storage are mostly based on allometric relationships (Brown 1997; Malhi and Grace 2000; Jepsen 2006; Lecointe et al. 2006; Green et al. 2007). Young forests are favoured for carbon sequestration, because of their ability to accumulate large amounts of organic matter in woody biomass and resistant litter (Thuille et al. 2000). Nutrients, especially nitrogen are known to be key determinants of carbon sequestration in various forest ecosystems (Kimmins 1996; San Jose 1995). More information is needed on carbon storage by tea plantations, which would fill the gap in the comparison with native forest vegetations and changes in agricultural land use. Information based on in situ measurements in tea plantations of above ground biomass (foliage and bush frame) and below ground biomass (tea root system) benchmark tea plantations with forests. No studies assessing carbon and nutrients allocation and stocks in tea plantations have been carried out in Kenya, yet these stocks could be an important carbon and nutrient source for maintaining crop productivity under variable weather conditions (Kamau et al. 2008). Indeed, the tea growers in Kenya have expressed much concern of the changing weather patterns in the prime tea growing areas, where harsh conditions like serious frost incidences and extended dry spells have become common (Anonymous 2000). The vulnerability of the tea industry in Sri Lanka to global warming and climate change has been reported by Wijerante (1996).

It is postulated that ageing of tea plantations can enhance adaptation of bushes to abiotic stress conditions (drought, cold, nutrient limitations). Quantifying budgets for $\mathrm{C}$ - and nutrient stocks will assist to explore the response of tea plantations to such abiotic stresses, and offer new insights for management interventions (uprooting, fertilization, irrigation). To quantify carbon and nutrient stocks and test the hypothesis that carbon and nutrient accumulation in tea plantations vary with age, we selected and examined a stand chronosequence of the tea plantations (14-, 29-, 43-, and 76- years old) with similar cultivation history, with the primary objectives of (a) determining temporal dynamics in standing biomass and dry matter partitioning in tea bushes varying in genotype, age and population density, (b) determining the $\mathrm{C}$ and nitrogen, phosphorus, potassium (NPK) stocks of tea plantations and thereby (c) assessing the consequences of $\mathrm{C}$ and NPK stocks for tea crop productivity and stability.

\section{Materials and methods}

Study area and experimental sites

The study was conducted in the Kericho region, the main tea growing area in the western highlands of Kenya. Four sites with uniformly managed mature tea plantations planted in 1988, 1973, 1959 and 1926 and with known past cultivation history were selected in January 2002. The ages of the tea plantations are defined based on 2002 as a reference year. It turned out that as a consequence of applying best management practices since about 1970 the use of low 
yielding seedlings was replaced by planting clonal cultivars with a higher yield potential. This change in genotype was associated with a higher plant density. Therefore, in our experiment the older plantations, defined as 43- and 76-year's, consisted of seedlings planted at relatively low densities: 6,730 and 7,179 plants $\mathrm{ha}^{-1}$, respectively (Table 1 ). In the two younger plantations defined as 14- and 29-years, an average yielding clone-TRFK 6/8 - was planted at relative high densities: 10,766 and 13,448 plants $\mathrm{ha}^{-1}$, respectively. As a consequence, the age of the plantations differed with 15 and 33 years within the two genotype-planting density groups, respectively. All tea plantations were managed according to best management practices.

The four sites are located within a radius of four kilometres from the Tea Research Foundation of Kenya (TRFK) Headquarters at Timbilil Estate, Kericho, at an elevation of 2110-2180 m above sea level, latitude $0^{\circ} 22^{\prime} \mathrm{S}$, and longitude $35^{\circ} 21^{\prime} \mathrm{E}$. The daily mean air temperatures ranged from $15.5^{\circ} \mathrm{C}$ to $18^{\circ} \mathrm{C}$ and a mean annual rainfall of $2150 \mathrm{~mm}$ (Stephens et al. 1992). The monthly radiation, temperature, rainfall, evapotranspiration and soil water deficits at Kericho between December 2002 and November 2004 and the detailed experimental design and treatments are reported in Kamau et al. (2008). In brief, the field experiments in each site were laid out in a split-split-block design consisting main blocks with two genotypes, sub-blocks with two age classes and five N-fertilizer rates $(0,50,100,200$ and $400 \mathrm{~kg} \mathrm{ha}^{-1}$ ) replicated three times completely randomized within sub-blocks. The total number of plots amounted to 60 .

All plots were managed uniformly. $\mathrm{P}$ and $\mathrm{K}$ were applied once a year at $100 \mathrm{~kg} \mathrm{P}_{2} \mathrm{O}_{5}$ ha $^{-1}$ year $^{-1}$ and $100 \mathrm{~kg} \mathrm{~K}_{2} \mathrm{O}$ ha $^{-1}$ year $^{-1}$, respectively.

Table 1 Characteristics of tea plantations varying in genotype, age, spacing and plant density

\begin{tabular}{llll}
\hline Genotype & Age (year) & Spacing $(\mathrm{m})$ & Plants per ha \\
\hline Clonal & 14 & $1.22 \times 0.76$ & 10,766 \\
& 29 & $1.22 \times 0.61$ & 13,448 \\
Seedling & 43 & $1.22 \times 1.22$ & 6,730 \\
& 76 & $1.52 \times 0.91$ & 7,179 \\
\hline
\end{tabular}

Sampling procedure and measurements

The experimental sites experienced a severe drought from February to April 2003 affecting shoot growth in most tea bushes. Subsequently, at least five bushes per plot at all the four sites were tagged depending on the visual symptoms as 'non-affected', 'mildly affected' and 'severely affected'. To avoid the extremes in terms of drought effects, one 'mildly affected' tea bush per plot in all the 15 plots per site was randomly selected and uprooted. These tea bushes were cut at the base of the stem and the excavation of all the roots to about $1 \mathrm{~m}$ depth done by hand based on the plant spacing area; e.g. $1.22 \times 0.76 \mathrm{~m}\left(10,766\right.$ plants $\left.\mathrm{ha}^{-1}\right)$ for the 14-year old plantation (Table 1). Each tea bush was partitioned into 'two leaves and a bud', maintenance foliage, twigs, stem, thick woody roots and thin feeder roots. Samples were taken for all plant components and oven-dried at $105^{\circ} \mathrm{C}$ to determine the dry matter content. For the "two leaves and a bud" material, the samples of three replicates were merged to obtain an adequate sample size for chemical analyses. All other plant samples were analysed separately using procedures and analyses outlined in the next section.

\section{Laboratory methods}

In the dried and ground samples organic $\mathrm{C}$ was determined using Walkley-Black method (IITA 1979a) while total $\mathrm{N}$ was determined by Kjeldahl digestion, distillation and titration method (Anderson and Ingram 1998). For total $\mathrm{P}$, dried sub-samples were ashed in a muffle furnace at $450^{\circ} \mathrm{C}$ for four and a half hours and $\mathrm{P}$ determined colourimetrically with Spectronic20 at $400 \mathrm{~nm}$ after complexing with a mixture of ammonium molybdate and ammonium metavanadate in concentrated nitric acid (IITA 1979b). For K, the ashed samples were digested with a mixture of double acid $\left(\mathrm{HCl}\right.$ and $\left.\mathrm{HNO}_{3}\right)$ and hydrogen peroxide in a ratio of $2: 3$ and extracted with $0.05 \mathrm{M} \mathrm{HCl}$ (IITA 1979a) and K determined by flame photometry.

Above- and belowground components

The above- and below ground biomass and C-stocks per bush were combined into three different classes, i.e. (i) Foliage consisting of the plucked two leaves and bud and maintenance foliage, (ii) Frame consisting of 
the woody twigs and stem, and, (iii) Roots consisting of woody thick roots and thin feeder roots. To determine the $\mathrm{C}$-stocks of the combined classes per bush, a weighted average from the individual organic carbon contents and dry mass in the plant organs was used.

\section{Data analysis and statistics}

Tea fields had the same cultivation history and the soil and weather conditions were uniform; therefore, we considered all samples as independent observations. The total number of observations was 60 . The ANOVA was done for a split-split-plot design with genotype (clone or seedling) as the main factor and age within genotypes as a sub-factor; nitrogen fertilization treatments were randomized within subblocks. Genotype (seedlings or clonal cultivar) and plant density were confounded; however, plant population affects tea stand productivity per unit land area during the establishment phase, but not in mature plantations (Wanyoko and Owuor 1995). The data were subjected to an ANOVA analysis using MSTAT-C (1993) statistical software package. Separation of the mean was done using the least significant difference (LSD).

\section{Results}

Above- and belowground biomass accumulation

$\mathrm{N}$ application rates did not show significant effects on total dry mass (DM) as shown in Tables 2 and 3; therefore, only the effects of age and genotype are considered in the further analyses. More dry mass accumulated in foliage, frame and roots of seedling bushes compared to the clonal bushes; the total biomass dry weight amounted to 9.0, 11.5, 13.6 and $19.8 \mathrm{~kg}$ per bush (Table 4) for the 14-, 29-, 43- and 76-year old plantations, respectively. However, this increase in dry mass per bush with age was not found per unit land area. Differences in total DM per ha between clonal and seedling plantations became very small; only within genotypes, viz. clonal cultivar or seedling, DM increased with age (Fig. 1).

Tea plants allocated most of the total dry mass in the woody tissue of the bush frame, i.e. twigs and stem $(81-85 \%)$, and only $10-15 \%$ and $5-6 \%$ to roots and foliage, respectively (Fig. 2). Genotype choice effected the allocation of dry mass in the foliage, frame and roots significantly (Table 4); DM per bush was higher in seedlings than in clonal cultivars. Whereas the clonal tea plants had a similar root biomass in the 14- and 29-year plantations, the seedling tea plants showed a difference between the 43- and 76-year plantation (Table 4). The root DM of the 76-year old bushes was significantly higher: 2.92 compared to $1.45 \mathrm{~kg} \mathrm{bush}^{-1}$. These differences were also consistent per unit area.

\section{Carbon stocks}

The weighted $\mathrm{C}$ contents $\left(\mathrm{g} \cdot \mathrm{kg}^{-1}\right)$ per age class in foliage, frame, and roots ranged from $390-460 \mathrm{~g} \mathrm{~kg}^{-1}$, from $460-480 \mathrm{~g} \mathrm{~kg}^{-1}$, and from 410-510 $\mathrm{g} \mathrm{kg}^{-1}$, respectively (Table 5). It shows that age effects within genotypes were small; however, clear genotypic differences existed between clonal and seedling plants. The $\mathrm{C}$ content of the foliage and roots of seedlings was higher than of clonal plants. The amount of carbon stored in the frame per bush increased with age from

Table 2 Total dry mass ( $\mathrm{kg} \mathrm{DM}$ bush $\left.^{-1}\right)$ of tea bushes differing in genotype and age at five different $\mathrm{N}-\mathrm{rates}\left(\mathrm{kg} \mathrm{ha}{ }^{-1}\right)$

\begin{tabular}{|c|c|c|c|c|c|c|c|}
\hline \multirow[t]{2}{*}{ Genotype } & \multirow[t]{2}{*}{ Age (year) } & \multicolumn{5}{|c|}{ N-rates } & \multirow[t]{2}{*}{ Mean } \\
\hline & & 0 & 50 & 100 & 200 & 400 & \\
\hline \multirow[t]{3}{*}{ Clonal } & 14 & 8.7 & 9.1 & 9.3 & 8.2 & 9.4 & 9.0 \\
\hline & 29 & 10.8 & 8.9 & 12.8 & 13.4 & 11.7 & 11.5 \\
\hline & Mean & 9.7 & 9.0 & 11.1 & 10.8 & 10.6 & 10.2 \\
\hline \multirow[t]{3}{*}{ Seedlings } & 43 & 17.8 & 12.5 & 11.1 & 13.6 & 12.4 & 13.5 \\
\hline & 76 & 18.9 & 19.5 & 20.6 & 21.3 & 19.2 & 19.9 \\
\hline & Mean & 18.4 & 16.0 & 15.9 & 17.5 & 15.8 & 16.7 \\
\hline \multicolumn{2}{|c|}{ Overall mean } & 14.0 & 12.5 & 13.5 & 14.1 & 13.2 & 13.5 \\
\hline
\end{tabular}


Table 3 Coefficient of variation $(\mathrm{CV})$ and least significant difference (LSD) for total dry mass (kg DM bush ${ }^{-1}$ )

\begin{tabular}{lccl}
\hline & Genotype & Age & N-rates \\
\hline CV $(\%)$ & 33 & 33 & 27 \\
$\operatorname{LSD}(P=0.05)$ & 0.8 & 0.8 & NS \\
\hline
\end{tabular}

$N S$ non significant

3.4 to $7.7 \mathrm{~kg} \mathrm{C}$ (Fig. 3a), reflecting the differences in plant density. By calculating $\mathrm{C}$ stocks per unit of area $\left(\mathrm{t} \mathrm{C} \mathrm{ha}{ }^{-1}\right.$ ), the difference in carbon stocks between the clonal and seedling genotypes became less. However, within seedlings and clonal plants a clear age effect on carbon stored in the frame still existed; older plantations stored more $\mathrm{C}$ in the frame. The $\mathrm{C}$ stock in the frame ranged from 37 to $62 \mathrm{tC} \mathrm{ha}^{-1}$ and from 35 to $55 \mathrm{t} \mathrm{C} \mathrm{ha}^{-1}$ for the clonal and seedling types, respectively (Fig. 3b). Storage of carbon in roots and foliage was relatively small, less than 5 and $10 \mathrm{t} \mathrm{C} \mathrm{ha}^{-1}$, respectively.

Nutrient contents

$\mathrm{N}$-contents $\left(\mathrm{g}_{\mathrm{kg}}{ }^{-1}\right)$ were highest in the seedling plantations, while P- and K-contents $\left(\mathrm{g}^{\mathrm{kg}} \mathrm{kg}^{-1}\right)$ were not affected much by age (Table 6). Genotype choice appeared to have a bigger influence on the nutrient contents than the age of the tea bush. For the aboveground parts, the highest NPK concentrations were found in the harvestable component of two leaves and a bud, followed by the maintenance foliage, twigs and stem. Similarly, the thin feeder roots had higher NPK nutrient concentrations than the thick woody roots. Whereas the twigs had higher $\mathrm{P}$ and $\mathrm{K}$ concentrations than in the stem organ in the clonal tea bushes, the differences were not significant for $\mathrm{P}$ in the older 43and 76-year seedlings, and for $\mathrm{K}$ it showed the opposite trend. Indeed some twigs in the older tea bushes were almost as thick and woody as the stems, and therefore less differences in NPK nutrient concentrations were found in these plant parts.

\section{Nutrient stocks}

The NPK stocks per unit area of land are presented in Table 7. The bush frame accounted for most of the stocks compared to foliage and roots. NPK stocks in the tea bush organs generally increased with age especially for the frame and roots. However, when the nutrient contents are converted to $\mathrm{kg} \mathrm{ha}^{-1}$, the pattern changed (Table 7) and only within tea types an increase of the nutrient stocks was associated with age. The clonal cultivar planted at higher densities stored considerably more nutrients in the frame per unit of land (ha).

\section{Nitrogen}

The $\mathrm{N}$ stocks per bush increased with age, amounting to $67.6,74.3,108.6$, and $166.6 \mathrm{~g} \mathrm{~N}^{-1}$ bush $^{-1}$ for the 14-, 29-, 43- and 76-year old plantations. The rise reflected the effects of age on $\mathrm{N}$-content as well dry mass. The increase of the $\mathrm{N}$ stock was also shown for the different parts: foliage, frame and roots. However, the fraction of $\mathrm{N}$ stored in the foliage decreased with age accounting for $26 \%, 22 \%, 19 \%$, and $16 \%$ in the 14-, 29-, 43- and 76-year old bushes, respectively. The highest fraction $(63-69 \%)$ of the $\mathrm{N}$ stock was present in the frame and was not affected by age class. The fraction of $\mathrm{N}$ stored in the roots $(9-16 \%)$ increased with age. Expressed per unit area, the total $\mathrm{N}$ stock increased with age from 732 to $995 \mathrm{~kg} \mathrm{~N} \mathrm{ha}^{-1}$ for the 14- to 29-year's clonal (HD) plantations, respectively (Table 7). In the seedling (LD) plantations of 43- and 76-year total $\mathrm{N}$ stocks increased from

Table 4 Dry mass of plant parts $\left(\mathrm{kg} \mathrm{DM} \mathrm{bush}{ }^{-1}\right)$ for tea plantations differing in genotype and age class

\begin{tabular}{|c|c|c|c|c|c|c|}
\hline \multirow[t]{2}{*}{ Plant part(s) } & \multicolumn{3}{|l|}{ Clonal } & \multicolumn{3}{|l|}{ Seedling } \\
\hline & 14-year ${ }^{\mathrm{a}}$ & 29-year & Mean $^{\mathrm{b}}$ & 43-year & 76-year & Mean \\
\hline Foliage & $0.6 \mathrm{a}$ & $0.6 \mathrm{a}$ & $0.6 \mathrm{~A}$ & $0.7 \mathrm{a}$ & $0.9 \mathrm{a}$ & $0.8 \mathrm{~B}$ \\
\hline Frame & $7.2 \mathrm{a}$ & $9.7 \mathrm{~b}$ & $8.5 \mathrm{~A}$ & $11.4 \mathrm{a}$ & $16.0 \mathrm{~b}$ & $13.7 \mathrm{~B}$ \\
\hline Roots & $1.2 \mathrm{a}$ & $1.2 \mathrm{a}$ & $1.2 \mathrm{~A}$ & $1.5 \mathrm{a}$ & $2.9 \mathrm{~b}$ & $2.2 \mathrm{~B}$ \\
\hline Total & $9.0 \mathrm{a}$ & $11.5 \mathrm{~b}$ & $10.3 \mathrm{~A}$ & $13.6 \mathrm{a}$ & $19.8 \mathrm{~b}$ & $16.7 \mathrm{~B}$ \\
\hline
\end{tabular}

${ }^{a}$ Values connected horizontally by the same lower-case letter are not significantly different at $P<0.05$.

${ }^{\mathrm{b}}$ Means connected horizontally by the same upper-case letter are not significantly different at $P<0.05$. 
Fig. 1 Total dry mass (DM) per ha in relation to age and genotype-density combinations. $14 \mathrm{HD}=14$ year old plantation at a high bush density. $29 \mathrm{HD}=29$ year old plantation at a high bush density. $43 \mathrm{LD}=43$ year old plantation at a low bush density. $76 \mathrm{LD}=76$ year old plantation at a low bush density

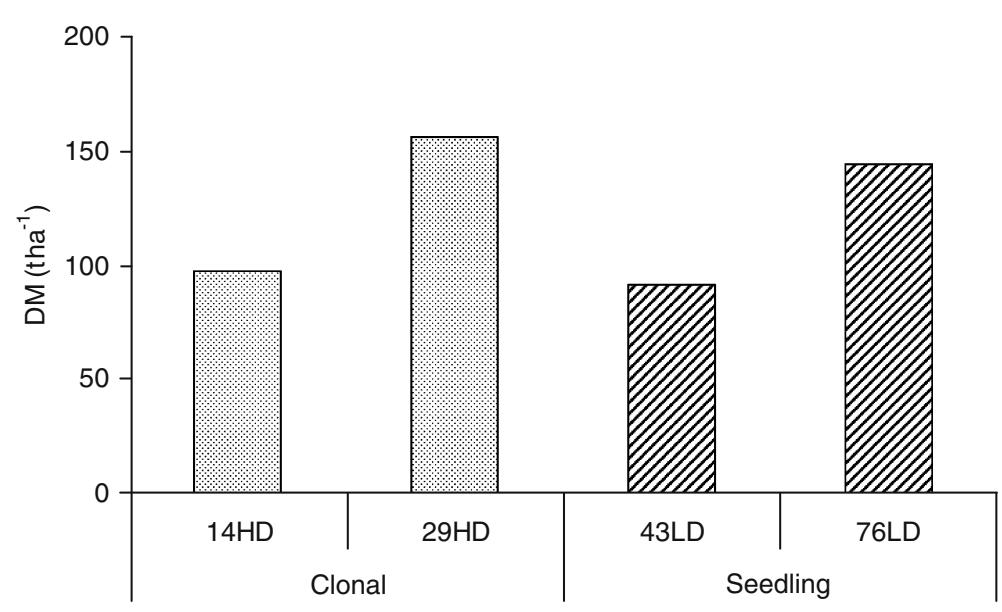

734 to $1,199 \mathrm{~kg} \mathrm{~N} \mathrm{ha}^{-1}$, respectively. Thus, $\mathrm{N}$ stocks per unit area increased with age within clonal and seedling tea plantations.

\section{Phosphorus}

P stocks increased from 7.2, 8.9, 10.0 to $12.8 \mathrm{~g} \mathrm{bush}^{-1}$, for the 14-, 29-, 43- and 76-year old tea plantations, respectively. The frame contributed $72-79 \%$ of the $\mathrm{P}$ storage, compared to $11-14 \%$ and $10-17 \%$ in the foliage and roots, respectively. The amount of $\mathrm{P}$ in the frame increased with age by about two-fold from 5.3 to $9.2 \mathrm{~g}$ per bush in the 14- and 76-year plantations. Differences in foliage and roots were minor. The increase of $\mathrm{P}$ stocks per unit area with age was found only within the 14- and 29-year clonal and the 43- and 76-year seedling plantations (Table 7). The total Pstocks varied from 67 to 92 and from 78 to $120.0 \mathrm{~kg}$ $\mathrm{ha}^{-1}$ for the seedling (LD) and clonal (HD) plantations, respectively.

\section{Potassium}

The K-stocks decreased from 71.3 to $66.3 \mathrm{~g}$ in the 14 - and 29-year clonal bushes and increased from 96.4 to $156.4 \mathrm{~g}$ in the 43- and 76 year seedling bushes, respectively. The lower K-stock in the 29-year clonal bush was caused by less $\mathrm{K}$ in the frame. Thus, the effect of age on K-stocks was most clear in the seedling bushes. The frame contributed $72-77 \%$ of the K stock per bush compared to $10-15 \%$ and $10-18 \%$, respectively, stored in foliage and roots. The increase in total $\mathrm{K}$ stock per unit area with age was consistent only within the same genotypedensity combination. The K-stocks ranged from 646 to 1,120 and from 775 to $901 \mathrm{~kg} \mathrm{~K} \mathrm{ha}^{-1}$ for the seedling and clonal plantations, respectively (Table 7).
Fig. 2 The fraction of dry mass per tea bush allocated in foliage, frame and roots for tea plantations differing in age class, and genotype-plant density combination

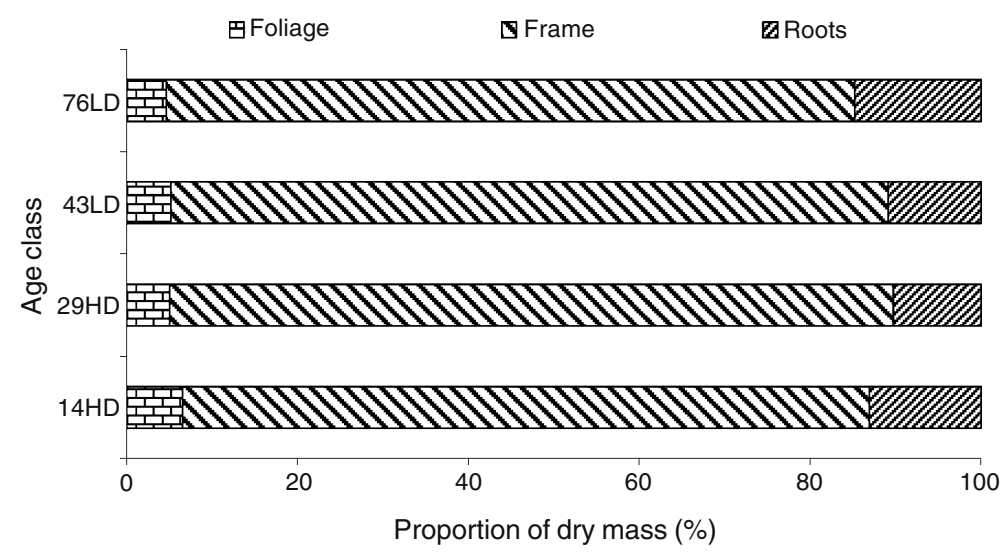


Table 5 Weighted carbon contents $\left(\mathrm{g} \mathrm{kg}^{-1}\right)$ of plant parts in tea bushes differing in genotype and age

\begin{tabular}{llllll}
\hline \multirow{2}{*}{ Plant organ(s) } & \multicolumn{2}{l}{ Clonal } & & & \multicolumn{2}{l}{ Seedling } \\
\cline { 2 - 3 } \cline { 6 - 6 } \cline { 5 - 6 } & 14-year & 29-year & & 43 -year & 76-year \\
\hline Foliage & 390 & 420 & & 460 & 440 \\
Frame & 470 & 470 & & 460 & 480 \\
Roots & 410 & 430 & & 510 & 500 \\
\hline
\end{tabular}

\section{Discussion and conclusions}

Biomass accumulation and $\mathrm{C}$ sequestration

We found that the woody tissue that forms the tea bush frame always had the highest DM irrespective of age and genotype-density combinations, which has also been reported by Dang (2005), Magambo and Cannel (1981), Ng'etich and Stephens (2001) and Wachira and Ng'etich (1999). Unlike in forests and tree plantations where foliage and fine root biomass decreases with age and maturity (Claus and George 2005), clear differences in foliage DM between genotypes/cultivars did exist in this study. It should be noted that plant density of the 29 year clonal plantation exceeded that of the 14 year's with 2,600 plants per ha (about 25\%). However, the effect of plant density will be mainly of importance during the establishment phase and become small in mature tea fields with a closed canopy (Wanyoko and Owuor 1995). So, it is assumed that the $\mathrm{C}$ - and nutrient stocks per unit land area will be less affected by plant density, than by the choice of the genotype (seedling or clone).

Generally, seedling tea bushes have a higher root DM (Burgess and Sanga 1994) when grown at a wider spacing, e.g. $1.22 \times 1.22 \mathrm{~m}$. We found more root biomass in seedling tea bushes; however, the root DM in the 43-year old plantation was much lower than in the 76-year plantation (Table 4). This shows that ageing also affects the allocation of assimilates to the roots. Less root biomass is associated with a lower root length density and thus may limit the uptake of water
Fig. 3 Carbon stocks and distribution in tea plantations differing in age and genotype-density combinations; $\mathrm{kg} \mathrm{C}$ bush $^{-1}$ (a) and $\mathrm{C} \mathrm{ha}^{-1}$ (b). (Error bars are SE of the means, $n=15$ )
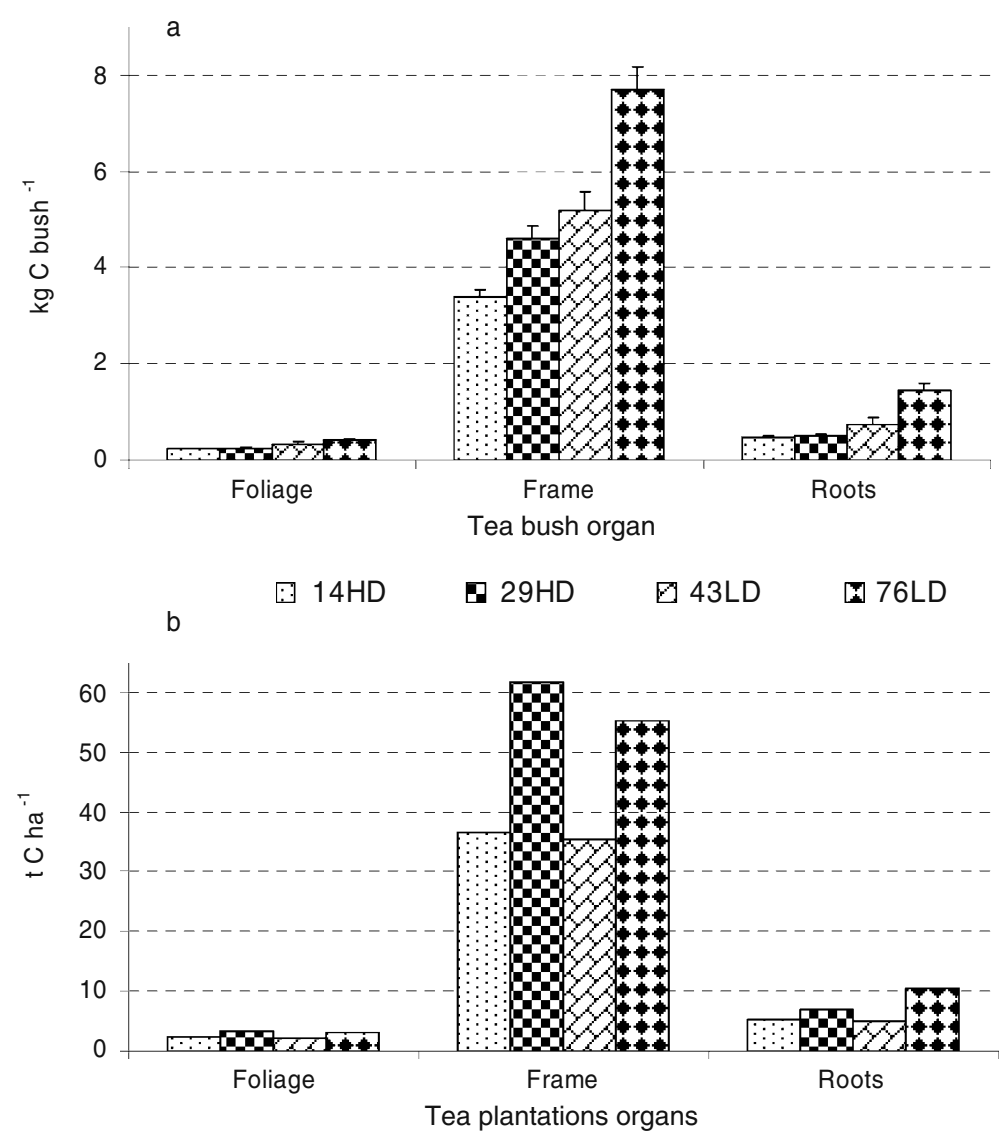
Table 6 NPK contents $\left(\mathrm{g} \mathrm{kg}^{-1}\right)$ in above- and belowground plant parts of tea bushes for different genotypes and age classes

\begin{tabular}{|c|c|c|c|c|c|c|c|}
\hline \multirow[t]{2}{*}{ Nutrient } & \multirow[t]{2}{*}{ Plant part } & \multicolumn{3}{|l|}{ Clonal } & \multicolumn{3}{|l|}{ Seedling } \\
\hline & & 14-year & 29-year & Mean & 43-year & 76-year & Mean \\
\hline \multirow[t]{6}{*}{$\mathrm{N}$} & Two leaves and bud & $34.5 \mathrm{a}$ & $34.4 \mathrm{a}$ & $34.5 \mathrm{~A}$ & $45.0 \mathrm{a}$ & $44.4 \mathrm{a}$ & $44.7 \mathrm{~B}$ \\
\hline & Maintenance foliage & $30.6 \mathrm{a}$ & $26.7 \mathrm{a}$ & $28.6 \mathrm{~A}$ & $29.4 \mathrm{a}$ & $27.4 \mathrm{a}$ & $28.4 \mathrm{~A}$ \\
\hline & Twigs & $8.1 \mathrm{a}$ & $7.2 \mathrm{a}$ & $7.6 \mathrm{~A}$ & $7.6 \mathrm{a}$ & $9.3 \mathrm{a}$ & $8.4 \mathrm{~B}$ \\
\hline & Stem & $4.1 \mathrm{a}$ & $4.1 \mathrm{a}$ & $4.1 \mathrm{~A}$ & $6.4 \mathrm{a}$ & $6.0 \mathrm{a}$ & $6.2 \mathrm{~B}$ \\
\hline & Thick woody roots & $5.6 \mathrm{a}$ & $4.8 \mathrm{a}$ & $5.2 \mathrm{~A}$ & $9.3 \mathrm{a}$ & $8.1 \mathrm{a}$ & $8.7 \mathrm{~B}$ \\
\hline & Thin feeder roots & $12.1 \mathrm{a}$ & $14.3 \mathrm{a}$ & $13.2 \mathrm{~A}$ & $14.3 \mathrm{a}$ & $16.1 \mathrm{a}$ & $15.2 \mathrm{~B}$ \\
\hline \multirow[t]{6}{*}{$\mathrm{P}$} & Two leaves and bud & $2.69 \mathrm{a}$ & $2.99 \mathrm{a}$ & $2.84 \mathrm{~A}$ & $2.82 \mathrm{a}$ & $2.87 \mathrm{a}$ & $2.85 \mathrm{~A}$ \\
\hline & Maintenance foliage & $1.87 \mathrm{a}$ & $1.94 \mathrm{a}$ & $1.91 \mathrm{~B}$ & $1.44 \mathrm{a}$ & $1.53 \mathrm{a}$ & $1.49 \mathrm{~A}$ \\
\hline & Twigs & $0.99 \mathrm{a}$ & $0.83 \mathrm{a}$ & $0.91 \mathrm{~B}$ & $0.56 \mathrm{a}$ & $0.63 \mathrm{a}$ & $0.60 \mathrm{~A}$ \\
\hline & Stem & $0.53 \mathrm{a}$ & $0.64 \mathrm{a}$ & $0.59 \mathrm{~A}$ & $0.57 \mathrm{a}$ & $0.58 \mathrm{a}$ & $0.58 \mathrm{~A}$ \\
\hline & Thick woody roots & $0.71 \mathrm{a}$ & $0.71 \mathrm{a}$ & $0.71 \mathrm{~A}$ & $0.77 \mathrm{a}$ & $0.79 \mathrm{a}$ & $0.78 \mathrm{~B}$ \\
\hline & Thin feeder roots & $1.05 \mathrm{a}$ & $1.03 \mathrm{a}$ & $1.04 \mathrm{~B}$ & $0.89 \mathrm{a}$ & $0.88 \mathrm{a}$ & $0.88 \mathrm{~A}$ \\
\hline \multirow[t]{6}{*}{ K } & Two leaves and bud & $21.9 \mathrm{~b}$ & $20.4 \mathrm{a}$ & $21.2 \mathrm{~B}$ & $19.5 \mathrm{~b}$ & $17.2 \mathrm{a}$ & $18.4 \mathrm{~A}$ \\
\hline & Maintenance foliage & $18.2 \mathrm{~b}$ & $17.8 \mathrm{a}$ & $18.0 \mathrm{~B}$ & $18.4 \mathrm{~b}$ & $16.8 \mathrm{a}$ & $17.6 \mathrm{~A}$ \\
\hline & Twigs & $7.7 \mathrm{~b}$ & $5.4 \mathrm{a}$ & $6.6 \mathrm{~B}$ & $5.9 \mathrm{a}$ & $5.7 \mathrm{a}$ & $5.8 \mathrm{~A}$ \\
\hline & Stem & $6.9 \mathrm{~b}$ & $4.4 \mathrm{a}$ & $5.7 \mathrm{~A}$ & $7.3 \mathrm{a}$ & $8.1 \mathrm{~b}$ & $7.7 \mathrm{~B}$ \\
\hline & Thick woody roots & $6.1 \mathrm{a}$ & $8.2 \mathrm{~b}$ & $7.2 \mathrm{~A}$ & $7.0 \mathrm{a}$ & $10.1 \mathrm{~b}$ & $8.6 \mathrm{~B}$ \\
\hline & Thin feeder roots & $8.5 \mathrm{~b}$ & $7.4 \mathrm{a}$ & $8.0 \mathrm{~A}$ & $10.7 \mathrm{~b}$ & $9.8 \mathrm{a}$ & $10.3 \mathrm{~B}$ \\
\hline
\end{tabular}

Values connected horizontally by the same lower-case letter are not significantly different at $P<0.05$.

Means connected horizontally by the same upper-case letter are not significantly different at $P<0.05$.

and nutrients under drought conditions (Burgess and Sanga 1994). In woody crop species genotypes significantly influenced root system development; fine and coarse roots responded positively to the availability of resources, indicating a whole root-system response to resource enrichment (Coleman 2007).

Table $7 \mathrm{~N}$-, P- and K-stocks $\left(\mathrm{kg} \mathrm{ha}^{-1}\right)$ in foliage, frame and roots of tea plantations differing in age class and genotype (Clone (C) or Seedlings (S))

\begin{tabular}{|c|c|c|c|c|c|}
\hline \multirow[t]{2}{*}{ Nutrient } & \multirow[t]{2}{*}{ Age class } & \multicolumn{3}{|c|}{ Plant parts } & \multirow[t]{2}{*}{ Total } \\
\hline & & Foliage & Frame & Roots & \\
\hline \multirow[t]{4}{*}{$\mathrm{N}$} & C-14 & 194 & 463 & 75 & 732 \\
\hline & C-29 & 215 & 686 & 94 & 995 \\
\hline & S-43 & 141 & 498 & 87 & 734 \\
\hline & S-76 & 187 & 818 & 194 & 1199 \\
\hline \multirow[t]{4}{*}{$\mathrm{P}$} & C-14 & 11 & 57 & 10 & 78 \\
\hline & C-29 & 15 & 93 & 12 & 120 \\
\hline & S-43 & 7 & 53 & 7 & 67 \\
\hline & S-76 & 11 & 66 & 15 & 92 \\
\hline \multirow[t]{4}{*}{$\mathrm{K}$} & C-14 & 118 & 571 & 86 & 775 \\
\hline & C-29 & 134 & 632 & 134 & 901 \\
\hline & S-43 & 81 & 498 & 67 & 646 \\
\hline & S-76 & 108 & 811 & 201 & 1120 \\
\hline
\end{tabular}

The low variation noted in C-contents within bush organs of the ageing tea classes was also observed in storage organs of crops of widely different biochemical composition (Vertregt and Penning De Vries 1987) and in a chronosequence of eastern Amazonia forests (Johnson et al. 2001). When a comparison was made with forests and mature plantation trees, the $\mathrm{C}$ stock of tea plantations was lower. In a chronosequence of pine plantations in Turkey, Peichl and Arain (2006) reported C-stocks of standing biomass of $0.27,37,54$, and $103 \mathrm{t} \mathrm{C} \mathrm{ha}^{-1}$ for 2-, 15-, 30-, and 65-year old stands. Similarly, Glenday (2006), estimated C stock for 10-year Eucalyptus saligna and 30-year Cupressus lusitanica plantations, and an undisturbed indigenous forest at Kakamega in western Kenya at 94, 108, and $356 \mathrm{t} \mathrm{C} \mathrm{ha}^{-1}$, respectively. Thus, the standing biomass $\mathrm{C}$ of tea plantations ranging from 43 to $72 \mathrm{t} \mathrm{C} \mathrm{ha}^{-1}$ is in the same magnitude of the $\mathrm{C}$ stored by tree plantations up to 30 years; this did not apply for the older plantations and indigenous forests.

Management of the tea bush by periodical pruning and constant removal of the apical buds and breakingback to maintain the plucking table had been suggested as the main reason for the low DM. Indeed, 
Magambo and Cannel (1981) attributed the low standing DM of tea compared to forest trees and $\mathrm{C}_{3}$ vegetative crops as due to the continual plucking that limits the amount of young photosynthetically active leaves as well as assimilate supply to other plant organs. Instead of standing biomass, the rate of DM increase per year would be a better indicator for the productivity of tea plantations. The annual rate of DM increase per unit area in plantations with clonal cultivars ranged from 1.8 to $2.2 \mathrm{t} \mathrm{ha}^{-1}$ year $^{-1}$ and from 1.3 to $1.4 \mathrm{t} \mathrm{ha}^{-1}$ year $^{-1}$ in those with seedling tea (Fig. 1). These values are within the range from 1.1 to $3.9 \mathrm{t} \mathrm{ha}^{-1}$ year $^{-1}$ reported by Maikhuri et al. (2000) for multipurpose tree species established in degraded and abandoned agricultural land at $1200 \mathrm{~m}$ altitude, respectively. The results show that younger tea plantations at higher plant population densities accumulate more $\mathrm{C}$ per unit area per year. So, there is a clear trade off between storage of C-reserves, which may contribute to adaptation of bushes to drought conditions, and the annual productivity under optimal conditions (Kamau et al. 2008). Trees are terrestrial carbon sinks (Houghton et al. 1998). A tea agroecosystem therefore will sequester carbon both in situ (biomass and soil) and ex situ (harvested shoots). Thus the accumulation of biomass in ageing tea plantations, though less than in tropical forests, imply a sustained carbon sequestration. The C sequestration in the soil of the ageing tea plantations was not assessed in this study, although the small differences in total organic $\mathrm{C}$ of $36,37,35$, and $33 \mathrm{~g}$ $\mathrm{kg}^{-1}$ reported by Kamau et al. (2008) for the 14-, 29-, 43-, and 76-year old tea plantations, respectively, suggest that the soil carbon stocks of these tea plantations did not vary much. As a consequence of regular pruning, crop residues may have reduced soil erosion and run-off and therefore soil fertility, especially the availability of $\mathrm{P}$, was maintained.

\section{Nutrient accumulation in biomass}

The $\mathrm{N}$ and $\mathrm{P}$ stocks increased with age of tea bushes irrespective of the genotype-density combination. The lowered K stock in the 29-year old clonal tea bushes could not be explained. However, this lack of response to ageing in $\mathrm{K}$ stocks was also observed in secondary forests in Brazil where 10-, 20-, and 40year old forests were compared and showed a dip in potassium stocks at the 20-year old, especially for the woody component (Johnson et al. 2001). Tea is primarily grown for the production of the young shoots ('two leaves and a bud'), that also determines made tea yield, rather than for the storage of assimilates in foliage, stems, twigs and roots (Matthews and Stephens 1998). The allocation of assimilates from source to sink is essential to growth and yield formation (Marschner 1989). Generally, with increasing amount of $C$ and nutrients reserves, the ratio between mobile and structural material increases as was shown for annual crops (Spiertz 1977). Although a high nutrient allocation to the young shoots ("two leaves and bud") may be desirable for made tea yields, generally, adequate stocks of nutrients in the non-harvestable parts will be important to maintain yield stability under adverse conditions. Higher C and NPK stocks contribute also to more soil carbon accumulation and nutrient cycling after pruning. The potential for recycling was estimated by Dossa et al. (2008) for open-grown coffee systems; the nutrients in biomass fractions susceptible to rapid turnover (leaves, twigs, fine roots) amounted to about $400 \mathrm{~kg} \mathrm{~N}, 20 \mathrm{~kg} \mathrm{P}$, $200 \mathrm{~kg} \mathrm{~K}, 400 \mathrm{~kg} \mathrm{Ca}$ and $150 \mathrm{~kg} \mathrm{Mg}$. We found the highest contents of nutrients in the "two leaves and a bud", the maintenance foliage and the thin feeder roots; the contents in the frame and the thick woody roots were much lower. However, the NPK stocks were mainly determined by the amounts in the frame due to a much higher DM. The total NPK stocks for tea plantations were much higher than for the opengrown coffee systems.

In conclusion, the results herein demonstrate that ageing of tea plantations is associated with increased stocks of carbon and major nutrients per bush and per unit area. The magnitude of increase differs between tea seedlings and clonal cultivars. Assessments of carbon and nutrient stocks should therefore be carried out per unit area to avoid effects of variation in population density. Tea bushes with higher NPK reserves may require lower fertilizer applications and will depend less on reduced nutrient uptake under adverse weather conditions. However, there is a trade-off for the investment in extra reserves by a loss of yield potential.

Acknowledgements The field and laboratory staff of Chemistry Department, Tea Research Foundation of Kenya (TRFK) provided invaluable assistance in data collection. The authors gratefully acknowledge the financial support from the Netherlands Organisation for the Advancement of Tropical Research (NWOWOTRO). This paper is published with the permission of the Director, TRFK. 
Open Access This article is distributed under the terms of the Creative Commons Attribution Noncommercial License which permits any noncommercial use, distribution, and reproduction in any medium, provided the original author(s) and source are credited.

\section{References}

Anderson JM, Ingram JSI (1998) Nitrogen. In: Chapter 6, Tropical soil biology and fertility: a handbook of methods, 2nd edition. CAB International, Wallingford, UK, pp. 70-75

Anonymous (2000) Topical issue: Frost damage report west of Rift. TRFK Q Bull 5:3-7

Anonymous (2004) Country programme action plan, 20042008, Government of Kenya and the United Nations development programme report, pp. 54

Brown S (1997) Estimating biomass and biomass change of tropical forest: a primer. FAO forestry paper no. 134, Food and Agriculture Organization, Rome, Italy

Burgess PJ, Sanga BNK (1994) Dry weight and root distribution of mature tea. Ngwazi Tea Research Unit Quarterly Report 16:14-18

Claus A, George E (2005) Effect of stand age on fine-root biomass and biomass distribution in three European forest chronosequences. Can J Res 35:1617-1625

Coleman M (2007) Spatial and temporal patterns of root distribution in developing stands of four woody crop species grown with drip irrigation and fertilization. Plant Soil 299:195-213

Dang MV (2005) Soil-plant nutrient balance of tea crops in the northern mountainous region, Vietnam. Agric Ecosyst Environ 105:413-418

Dossa EL, Fernandes ECM, Reid WS, Ezui K (2008) Aboveand belowground biomass, nutrient and carbon stocks contrasting an open-grown and a shaded coffee plantation. Agrofor Syst 72:103-115

FAO (1999) State of the world's forests. Food and Agriculture Association of the United Nations (FAO), Rome

Glenday J (2006) Carbon storage and emissions offset potential in an East African tropical rainforest. For Ecol Manag 235:72-83

Green C, Tobin B, O'Shea M, Farrell EP, Byrne KA (2007) Above- and belowground biomass measurements in an unthinned stand of Sitka spruce (Picea sitchensis (Bong) Carr.). Eur J For Res 126:179-188

Houghton RA, Davidson EA, Woodwell GM (1998) Missing sinks, feedbacks and understanding the role of terrestrial ecosystems in the global carbon balance. Glob Biogeochem Cycles 12:25-34

Jaetzold R, Schmidt H (eds) (1982) Natural conditions and Farm management information. In: Farm management handbook of Kenya. vol. 2. vol. /A. Ministry of Agriculture, Nairobi, p 397

Jepsen MR (2006) Above-ground carbon stocks in tropical fallows, Sarawak, Malaysia. For Ecol Manag 225:287-295

Johnson CM, Vieira ICG, Zarin DJ, Frizano J, Johnson AH (2001) Carbon and nutrient storage in primary and secondary forests in eastern Amazonia. For Ecol Manag $147: 245-252$
IITA (1979a) Selected methods for soil and plant analysis. Manual series no 1, International Institute of Tropical Agriculture, Ibadan, Nigeria, pp. 70

IITA (1979b) Colorimetric determination of $\mathrm{P}$ in plant tissue (vanado-molybdate method) In: Selected methods for soil and plant analysis. Manual series no 1, International Institute of Tropical Agriculture, Ibadan, Nigeria, pp. 53

Kamau DM, Spiertz JHJ, Oenema O, Owuor PO (2008) Productivity and nitrogen use of tea in relation to plant age and genotype. Field Crops Res. DOI 10.1016/j.fcr.2008.03.003

Kimmins JP (1996) Importance of soil and role of ecosystem disturbance for sustainable productivity of cool temperate and boreal forest. Soil Sci Soc Am J 60:1643-1654

Lecointe S, Nys C, Walter C, Forgeard F, Huet S, Recena P, Follain S (2006) Estimation of carbon stocks in a beech forest (Fougeres Forest-W. France): extrapolation from the plots to the whole forest. Ann For Sci 63:139-148

Magambo MJS, Cannel MGR (1981) Dry matter production and partitioning in relation to yield of tea. Exp Agric 17:33-38

Maikhuri RK, Semwal RL, Rao KS, Singh K, Saxena KG (2000) Growth and ecological impacts of traditional agroforestry tree species in Central Himalaya, India. Agrofor Syst 48:257-272

Malhi Y, Grace J (2000) Tropical forests and atmospheric carbon dioxide. Trends Ecol Evol 15:332-337

Marschner H (ed) (1989) Yield and the source-sink relationship. In: Mineral nutrition of higher plants. Academic, London, pp 115-153

Matthews RB, Stephens W (1998) CUPPA-Tea: A simulation model describing seasonal yield variation and potential production of tea. 1. Shoot development and extension. Exp Agric 34:345-367

MSTAT-C (1993) A micro-computer program for the design, management, and analysis of agronomic research experiments, MSTAT distribution package, MSTAT development team, Michigan State University, USA

Ng'etich WK, Stephens W (2001) Responses of tea to environment in Kenya. II. Dry matter production and partitioning. Exp Agric 37:343-360

Oglethorpe J, Oliech L (1992) Kenya indigenous conservation forest project. In: Piearce GD, Gumbo DJ (eds) The Ecology and management of indigenous forests in southern Africa, Proceedings of an international symposium, Zimbabwe. The Forestry Commission, Harare, Zimbabwe, pp 279-282

Peichl M, Arain MA (2006) Above- and belowground ecosystem biomass and carbon pools in an age-sequence of temperate pine plantation forests. Agric For Meteorol 140:51-63

San Jose JJ (1995) Environmentally sustainable use of the Orinoco savannas. Sci Guaianae 5:175-194

Sharrow SH, Ismail S (2004) Carbon and nitrogen storage in western Oregon agroforests, tree forests, and pastures. Agrofor Syst 60:123-130

Sombroek WG, Braun HMH, van der Pouw BJA (1980) Exploratory soil map and agro-climatic zone map of Kenya, scale 1:1,000,000. Kenya Soil Survey, Nairobi, p 56

Spiertz JHJ (1977) The influence of temperature and light intensity on grain growth in relation to the carbohydrate and nitrogen economy of the wheat plant. Neth J Agric Sci 25:182-197 
Stephens W, Othieno CO, Carr MKV (1992) Climate and weather variability at the Tea Research Foundation of Kenya. Agric For Meteorol 61:219-235

Thuille A, Buchmann N, Schulze ED (2000) Carbon stocks and soil respiration rates during deforestation, grassland use and subsequent Norway spruce afforestation in southern Alps. Tree Physiol 20:849-857

Vertregt N, Penning De Vries FWT (1987) A rapid method for determining the efficiency of biosynthesis of plant biomass. J Theor Biol 128:109-119
Wachira FN, Ng'etich WK (1999) Dry-matter production and partition in diploid, triploid and tetraploid tea. J Hortic Sci Biotechnol 74:507-512

Wanyoko JK, Owuor PO (1995) Effects of plant densities and nitrogen fertilizer rates on the yield of mature seedling Kenyan tea. Tea 16:14-20

Wass P (1995) Kenya's indigenous forest status. Management and conservation. IUCN, Gland, Switzerland

Wijerante MA (1996) Vulnerability of Sri Lankan tea production to global climate change. Water Air Soil Pollut 92:87-94 